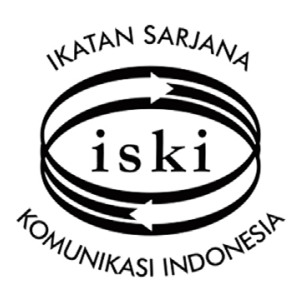

Jurnal Komunikasi ISKI, Vol. II (02), 2017. 92-96

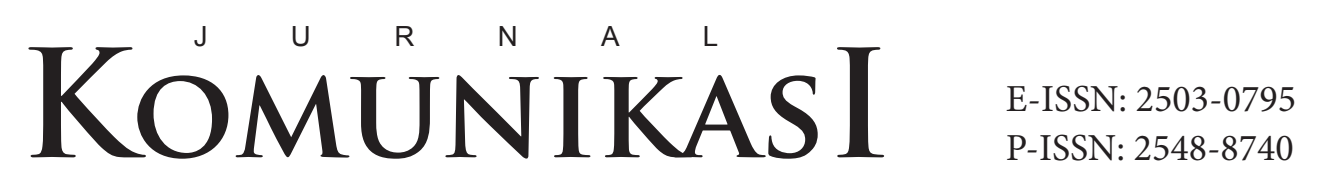

IKATAN SARJANA KOMUNIKASI INDONESIA

\title{
Communication Pattern of Women Migrant Workers Family at Sliyeg District in Indramayu - West Java
}

\author{
http://dx.doi.org/10.25008/jkiski.v2i2.88 \\ Slamet Mulyana ${ }^{1}$, Duddy Zein ${ }^{2}$, Agus Setiawan ${ }^{3}$ \\ ${ }^{1.2 .3}$ Faculty of Communication Science, Padjadjaran University \\ Jl. Hegarmanah, Jatinangor, Sumedang, Jawa Barat 45363 - Indonesia \\ ${ }^{1}$ slamet.mulyana@unpad.ac.id; ${ }^{2}$ zein@unpad.ac.id; ${ }^{3}$ agus.setiawan@unpad.ac.id
}

\begin{abstract}
The purpose of this study is to determine and analyze the factors that affect the communication of migrant workers family, the relationship between parents and children in a migrant worker family, and communication styles of parents in the migrant workers family at Sliyeg district in West Java. The method used in this research is a descriptive quantitative method, with the research at Sliyeg district in Indramayu regency using a persuasive selection. The collection of data has been obtained through questionnaires, interviews and observations of respondents numbering 40 family heads of the migrant workers. The results showed that the characteristics of the family heads of migrant workers namely; age, education level, occupation, income level, the number of children and of dependents which have been driving factors making them (husbands) to allow their wives to become migrant workers. The physical and social environments are the important factors affecting the interaction and communication patterns of migrant workers family. The relationship level between parents and children in the communication of migrant worker family works pretty well. The style of parent communication in the migrant workers family has encouraged a mutual communication between parents and children.
\end{abstract}

Key Words: Women Migrant Workers, Family Communication, Communication Patterns

\begin{abstract}
Abstrak
Tujuan penelitian ini adalah ingin mengetahui dan menganalisis faktor-faktor yang mempengaruhi komunikasi keluarga buruh migran, tingkat relasi orang tua dan anak dalam komunikasi keluarga buruh migran, dan gaya komunikasi orang tua dalam komunikasi keluarga buruh migran di Kecamatan Sliyeg Kabupaten Indramayu, Jawa Barat. Metode yang digunakan dalam penelitian ini adalah metode Deskriptif Kuantitatif, dengan wilayah penelitian di Kecamatan Sliyeg Kabupaten Indramayu yang dipilih secara pesuasif. Pengumpulan data diperoleh melalui penyebaran angket, wawancara dan observasi dari responden sebanyak 40 orang kepala keluarga buruh migran. Hasil penelitian menunjukkan bahwa karakteristik kepala keluarga buruh migran yaitu usia, tingkat pendidikan, jenis pekerjaan, tingkat penghasilan, jumlah anak dan jumlah tanggungan keluarga merupakan faktor pendorong yang menyebakan mereka mengizinkan istrinya untuk menjadi buruh migran. Kondisi lingkungan fisik dan kondisi lingkungan sosial merupakan faktor penting yang mempengaruhi pola interaksi dan pola komunikasi keluarga buruh migran. Tingkat relasi orang tua dan anak dalam komunikasi keluarga buruh migran berjalan cukup baik. Gaya komunikasi orang tua dalam komunikasi keluarga buruh migran mendukung adanya komunikasi timbal balik antara orang tua dengan anak.
\end{abstract}

Kata Kunci: Buruh Migran Perempuan, Komunikasi Keluarga, Pola Komunikasi 


\section{Introduction}

Nationally Indramayu district occupies the first position as the region which sent most of migrant workers notably to the Middle East and the Far East; and Sliyeg district is one of the districts in Indramayu sending most of its labors as migrant workers abroad. Nevertheless, labors living in every district in Indramayu who go abroad as migrant workers is quite high in number. Being a migrant worker is an alternative option for many Indramayu residents to get out from the crush of economic hardship. Decision of women migrant workers showed that the change of women's role was initially to become more productive rather than reproductive. When the decision was taken by the majority of women it would cause internal problems in the family, and at the same time has a great impact in terms of the functions and domestic roles of women in the family.

The family is the primary educational institution for a child. W. Bennet in Hastuti (2008) and Pramono et.al (2017) states that the family is the most effective place where a child obtaines health, education and welfare for his life, and the condition of biological, psychological and educational well-being of a child definately depend on the family. Family functions can be of a double meaning, namely the function of family in the community and family functions against individual members. In the primary institution, a child experiences on what is so-called "parenting". The success of a child in their social relation depends on parenting applied by parents in the family. Generally, children care has been embodied in the forms of caring, nurturing, teaching, and guiding.

One of the domestic roles of women in the family is parenting. Parenting in the family is also closely related to communication patterns and gender relations between men and women therein. In family, the economic responsibility is fully carried out by the father (husband), and the role of mother in caring for children is very dominant. In such cases, the mother completely participates in the domestic and productive sectors - father deals only to meet the material needs of the family. Parenting applied would be different if mother in a family also takes care of the productive and domestic sector -- or so-called a double role.

The loss of one element in the family (i.e. mother/ wife), has impacted the imbalanced atmosphere in the family. The balance in the family itself occurs when there is a harmonious relationship (interac- tion) between father / husband and mother / wife, between father and son, and between child and mother (Djamarah, 2004). Sociologically, the family relationship between inner and outer structures in the family is mother-each father and son has a hope. Thus, there must be functional relationship aong family members in order to reach that expectation. If a family loses one of its elements, then it is likely that the family will experience imbalanced o that an ideal family aspired is too difficult to be met. This study focuses on family communication patterns of female migrant workers. Based on background description, the problem of this research is formulated as follows: "How can communication patterns of female migrant workers family at Sliyeg district, Indramayu be?"

The purpose of this study is to find out: First, the factors that have affected the communication pattern of the migrant workers family at Sliyeg district, in Indramayu regency. Second, the relationship level between parents and children of migrant workers family at Sliyeg district; and third, the communication style of parents in migrant workers family at Sliyeg district, Indramayu regency.

\section{Theoretical Framework}

The family is the smallest unit of social unity that has a very important role in fostering members. Each member of family has to be able to have skills in instilling a role in accordance with the position. Basically, the family can be divided into two: nuclear family and spacious family (extended family). The family as the primary institution so it is the first and foremost place for the children before knowing the environment outside Hartoyo (1987) as cited in (Ritonga, 1996) suggests that in a broader sense, a family is the smallest social institution of society consisting of a group of men living together with their matrimony, blood relationship and adoption.

Judy C. Pearson (1993) argued that communication has two public functions. First, for the survival of themselves including physical safety, an increased personal awareness. Second, for the survival of society-- precisely to improve social relations and develop the existence of a society. In a family environment, communication between family members is also a very important notably between parents and children, where communication as a tool or mediation bridge among members of the family. The poor quality of communication within the family would be at risk for the unity and harmony in the family itself. 
As an example: the factors causing the emergence of juvenile deliquency has resulted a poor interpersonal communication in the family so as these teens might get wrong association. The position and function of a family in human life is primary and fundamental. The family essentially forms a container for each member, notably the children who are still under the guidance of responsibility of their parents.

Family communication can take place on a reciprocal basis and turning from parent to child, or from child to parent, and or from child to child. In family communication, the parents' responsibility is to educate children thus the communication would occur within the valued family education thereof. There are a number of inherited norms of parents on children, such as religious, moral, social and ethics norms and also norm in aesthetics.

Communication in the family is very important in providing mediation for family members in order to express their needs and desires in the dimension of mutual caring. In line of this case, open and honest communication have resulted an atmosphere athat allow family members to express their differences and affection in mutual feelings as well as mutual respect. Communication through family members can solve the problems arising in all families that may happen as categorized two forms, namely instrumental and affective communications. Instrumental communication is the exchange of factual information that makes people to fulfill the family functions -- such as telling a child when and where picking him/her up at school and telling your partner (husband or wife) to remind something. Meanwhile, the affective communication is how family members communicate to each other in sharing the joys and sorrows which involve feelings and emotions.The family functions work very well using instrumental communication, but it is difficult to apply it in the affective communication. Imagine, if among family members communicates only use an instrument every day, it would of course result strained and clumsy atmosphere. Therefore, a healthy family is a family that can communicate well in both instrumental and affective areas in order the purpose of an appropriate communication can be achieved as expected.

\section{Material and Methodology}

The method used in this research is a descriptive method to collect, collate, analyze and interpret the data found. The use of descriptive method in this re- search is intended to describe the facts and characteristics of the object and subject sistematically-like the family communication patterns of female migrant workers at Sliyeg district, Indramayu regency. Deciding the research area conducted with purposive considerations, the region of the study sites with the most number of cases is determinant. There are 40 people and respondents were used as samples based on certain consideration of the proper research purposes.

The first variable in this study are the factors that influence the pattern of family communication. In accordance the understanding of study area condition, the factors that influence the pattern of family communication will be limited to family characteristics and environmental conditions. Family characteristics consist of parental education level, occupation of parents, family income, family size, number of children in the family, the age, child and parents in women migrant workers family. Nevertheless, the environmental conditions are with respect to physical and social environments of women migrant workers family.

The second variable in this study is the relationship between parents and children. In line with the understanding of the study area condition, the relationship between parents and children include the intensity and values as reference in the relationship between parent and children, and family activities involving parents and children therein.

The third variable of this research is the communication style of parents in the family communication. Concerning the understanding of study area condition, the style of parent communication include the adjustment ability of parent when communicating with children in the communication of women migrant workers family.

\section{Results and Discussion}

Characteristics of respondents are relatively young age (productive age) with low education level, working as farming or casual laborers, lowest income level and expenditure levels, the number of children and dependents, and the ownership of precious goods have influenced the behavior of migrant workers women family which are as driving factors that make them (husbands) allow their wives to become migrant workers. Direct and indirect communication has also been an issue of female migrant workers. Physical environmental conditions such as the status of house ownership or property and physical 
condition of the house have been quite good including the facilities available in the house such as bedrooms for family members, especially children, bathing and washing facility, toilet (MCK), area for the moving family members notably children, their land up to water resources supplies enabling the migrant workers family to carry out their daily living activities smootly. Such condition let them increase their intensity of communication among family members sufficiently.

Social environment, like the activity of routine interaction between members of migrant workers family with neighbors including the type of selected subject when interacting, their involvement in public organizations and various types of organization in the entire community around them, as well as positive perceptions to public organizations have enabled them to do social activities with local communities steadily, so that they could build and develop an effective communication with family thereof.

Regarding to the relationship between parents and children in family communication, the results showed that most of respondents $(72.5 \%)$ provide a special time every day to interact and communicate with their children. The time to do so is usually in the mornings before starting each activity, in the evenings and at nights when they are at rest. The other interaction form of migrant workers family is to eat altogether where most of respondents (95\%) do this activity. Based on interviews with some respondents, they say that when they are being eating together they could be of 'chating' each other, even if the activity is not routinely done every day.

Interesting things gained from research is that most of respondents (77.5\%) are not accustomed to discuss with children. For them, in accordance with the level of education, it is 'awkward' to discuss in such a way. Even so, the knowledge on children's issues is quite well, where the majority of respondents $(77.5 \%)$ claimed that they know about their own problems. The knowledge has been gained directly from children as well as many kinds of informations from relatives or neighbors nearby. Information on children might also sometimes be obtained from school or Koran place.

Pertaining to the regulations applied in the family, the answer of respondent are divided evenly-half of respondents said 'yes' and another half said 'no'. Those who have applied specific rules for the consideration from an early age where children need to be guided they could maintain the attitude and behavior when interacting with others. While those who do not apply the special rules in the house argue that they have been already described in comprehensive way by teachers at school or Koran place. In line with these regulations, it is also asked about the attitude of parents to impose penalties to children who made mistakes. With regard to that, the majority of respondents $(82.5 \%)$ stated that they give more 'punishment' orally in the form of warning or advice.

In term of the closeness or propinguity between parents and children, the majority of respondents (95\%) sought and felt quite close to children. They think they know where their children are and understand the problems of children may face. This condition is one of the impacts of development efforts and advocacy made by some community leaders, rural and districts functionaries who have conducted it continuously and sustainably. It is worth to highlight the study area is at Majasari Sliyeg district as a pilot region in Indramayu regency in term of fostering the migrant workers family.

Research outcome on the communication style of parents in family communication indicates that most of respondents (85\%) have a habit to teach the local language to their children. All respondents also speak the local language in daily interactions with children. Local languages which is so-called 'Dermayon' used daily in communities of Sliyeg and also peole living in other parts of Indramayu regency. It is a mixed language between rough Sundanese and Javanese which is somewhat similar to the language used by those people living in districts and its surrounding area of Indramayu and Cirebon city. According to them, based on interviews with some respondents by teaching and using local languages, the communication and interaction with children are better, and the children became accustomed to use the language in everyday interaction with community in its surrounding area.

The other thing that became a way in the parent communication is the habit of the respondents to explain the origin and genealogy of families to their children. Most respondents (60\%) feel that the explanation of the family tree will make children aware of their origin and their existence thereof. This is consistent with the opinion that the understanding of the origins of children is the most fundamental thing with respect to the identity of a person that would affect the formation and development of one's personality. 
The style of parent communication has been concerning with the habit of teaching manners and of giving a praise as tribute to children. By doing so, children have come to know and understand 'what is right' and 'what is wrong' in accordance with the prevailing values in society. An understanding of manners should be started when the kids were little and it becomes a very important provision when children have to interact with the surrounding community. In addition, it can also be seen that most of respondents (85\%) used to give praise as a form of appreciation when children do good things in their attitudes and behavior that make them happy.

\section{Conclusion}

In conclusion based on the description in the previous section, recommendations in the aforementioned research as follows: -- Firstly, the main characteristics of migrant workers family, namely age, education level, occupation, income level, number of children and dependents which are the driving factors that make them (husbands) allow their wives to become migrant workers. Physical environmental conditions such as the status of house ownership or property including the facilities available such as bedroom for family members, notably children, the availability of bathing and washing, toilet (MCK) in the house, area for children activity up to water resources supplies for family are important factors that have affected the communication patterns of migrant workers family. Besides the social environment, such as interaction among members of migrant workers family with neighbors including the selected subject type when interacting, their involvement in public organizations and organization types in the society, as well as their perceptions in social organization are also important as forms of interaction and communication with migrant workers family.

Secondly, the relationship level between parents and children in the communication with migrant worker family run well. In term of their understand- ing, it needs to provide time for them-- the need to conduct joint activities such as eating together even if not routinely --, their knowledge of parents on the presence of children-- the awareness of parents to adopt certain rules and penalties are carried out orally-and the closeness between parents and children. The only thing that has not been done yet is the habit of discussion among the entire members of family.

Thirdly, the style of communication parents in migrant workers family has supported mutual communication between parents and children. It can be seen from the efforts of parents in teaching regional languages once spoken in local language -- the efforts of parents to explain the existence of families with regard to the origin and genealogy of the family to chidren -- the habit of parents to teach more on values of manners and also social values in the efforts of granting awards to children in the form of praise and advice.

\section{References}

Djamarah, S. B. (2004). Pola Komunikasi Orang Tua dan Anak dalam Keluarga (Sebuah Perspektif Pendidikan Islam). Jakarta: Rineka Cipta.

Hastuti, D. (2008). Pengasuhan: Teori dan Prinsip Serta Aplikasinya di Indonesia. Departemen Ilmu Keluarga dan Konsumen, FEMA, IPB. Bogor.

Pearson, J. C. (1993). Communication in the Family: Seeking Satisfaction in Changing Times. Pearson College Division.

Pramono, F., Lubis, D. P., Puspitawati, H., \& Susanto, D. (2017). Communication Pattern Family Typology of High School Adolescents in Bogor - West Java. Jurnal Komunikasi Ikatan Sarjana Komunikasi Indonesia, 2(1), 20-26.

Ritonga, A. H. (1996). Fungsi Keluarga dalam Meningkatkan Kualitas Sumber Daya Manusia Daerah Sumatera Utara. Departemen Pendidikan dan Kebudayaan, Republik Indonesia. Retrieved from https://books.google.co.id/ books?id=9O3kAAAAMAAJ 